\title{
DNA damage in children and adolescents with cardiovascular disease risk factors
}

\author{
MARIELE KLIEMANN ${ }^{1}$, DANIEL PRÁ ${ }^{2,3}$, LUIZA L. MÜLLER ${ }^{4}$, LIZIANE HERMES ${ }^{4}$, \\ JORGE A. HORTA ${ }^{2}$, MIRIAM B. RECKZIEGEL ${ }^{2}$, MIRIA S. BURGOS ${ }^{2}$, SHARBEL W. MALUF $^{5}$, \\ SILVIA I.R. FRANKE ${ }^{2,4}$ and JULIANA DA SILVA ${ }^{1}$ \\ ${ }^{1}$ Programa de Pós-Gradução em Biologia Celular e Molecular Aplicada à Saúde, \\ Universidade Luterana do Brasil, Av. Farroupilha, 8001, 92425-900 Canoas, RS, Brasil \\ ${ }^{2}$ Programa de Pós-Graduação em Promoção da Saúde, Universidade de Santa Cruz do Sul, \\ Av. Independência, 2293, 96815-900 Santa Cruz do Sul, RS, Brasil \\ ${ }^{3}$ Programa de Pós-Graduação em Saúde e Comportamento, Universidade Católica de Pelotas, \\ Rua Almirante Barroso, 1202, 96010-280 Pelotas, RS, Brasil \\ ${ }^{4}$ DEDFIS, Universidade de Santa Cruz do Sul, Av. Independência, 2293, 96815-900 Santa Cruz do Sul, RS, Brasil \\ ${ }^{5}$ Serviço de Genética Médica, Hospital de Clínicas de Porto Alegre, \\ Rua Ramiro Barcelos, 2350, 90035-903 Porto Alegre, RS, Brasil
}

Manuscript received on April 29, 2011; accepted for publication on November 23, 2011

\begin{abstract}
The risk of developing cardiovascular disease (CVD) is related to lifestyle (e.g. diet, physical activity and smoking) as well as to genetic factors. This study aimed at evaluating the association between CVD risk factors and DNA damage levels in children and adolescents. Anthropometry, diet and serum CVD risk factors were evaluated by standard procedures. DNA damage levels were accessed by the comet assay (Single cell gel electrophoresis; SCGE) and cytokinesis-blocked micronucleus (CBMN) assays in leukocytes. A total of 34 children and adolescents selected from a population sample were divided into three groups according to their level of CVD risk. Moderate and high CVD risk subjects showed significantly higher body fat and serum CVD risk markers than low risk subjects $(P<0.05)$. High risk subjects also showed a significant increase in DNA damage, which was higher than that provided by low and moderate risk subjects according to SCGE, but not according to the CBMN assay. Vitamin C intake was inversely correlated with DNA damage by SCGE, and micronucleus (MN) was inversely correlated with folate intake. The present results indicate an increase in DNA damage that may be a consequence of oxidative stress in young individuals with risk factors for CVD, indicating that the DNA damage level can aid in evaluating the risk of CVD.
\end{abstract}

Key words: cardiovascular diseases, Micronucleus test, Comet assay, diet, anthropometry, child, adolescent.

\section{INTRODUCTION}

Cardiovascular diseases (CVD) are multifactor slow-progressing pathologies (Argiles et al. 1998)

Correspondence to: Juliana da Silva

E-mail: juliana.silva@ulbra.br that might start forming early in childhood, but manifest later in middle age and is a leading cause of death (Lloyd-Jones et al. 1999).

The risk of developing CVD is related to a set of characteristics or risk factors that interact to 
increase the probability of developing CVD; these characteristics include metabolic and hemodynamic disturbances, as well as an unhealthy diet and physical inactivity (Wu 1999).

Correlations between the extent of atherosclerotic depositions and CVD risk factors (e.g. serum lipids disturbances) have been observed in an autopsy study with young subjects whose deaths were unrelated to CVD itself (Berenson et al. 1998). Such evidence indicates that some young individuals with changes in CVD risk factors may be at higher CVD risk later in life. In agreement with this, the risk of CVD outcomes in the elderly is two-fold higher in individuals who were obese during adolescence (Must et al. 1992).

Several studies have demonstrated that oxidative stress can contribute to CVD progression (Wattanapitayakul and Bauer 2001). For instance, a diet rich in saturated fat and poor in micronutrients with antioxidant properties (such as vitamins A and C) may increase the formation of oxidized lipids and reduce antioxidant reactions, leading to oxidative stress (Poulsen 2005, Obrenovich et al. 2011).

Therefore, this study evaluated the association between risk factors for CVD and DNA damage, which can be defined as either primary (potentially reparable) and permanent (chromosome breaks/ losses lesions) in children and adolescents with variable levels of CVD risk.

\section{MATERIALS AND METHODS}

\section{STUDY POPULATION}

The study protocol was approved by the ethics committee of Universidade de Santa Cruz do Sul, RS, Brazil (references 678/04 and 358/06). The guardians of all subjects gave us a written informed consent after the study was explained to them.

Between March and August 2005, we recruited male and female individuals aged 6-18 years to be included in a population study (with around 600 subjects) designed to evaluate the prevalence of
CVD risk factors (overweight, body fat increase, arterial hypertension, increased fasting glucose, increased LDL and triglycerides, and decreased HDL) in children and adolescents of Santa Cruz do Sul, RS, Brazil. From this sample, three groups of subjects were randomly recruited between June and July 2006: 1) those subjects with no CVD risk factors; 2) those subjects with one or two CVD risk factors; and 3) those subjects with three or more CVD risk factors. The number of subjects in each group was calculated to provide power of $\geq 80 \%$ to detect a 2.5 -fold increase in DNA damage with a coefficient of variance of $80 \%$ with the use of a one-sided statistical significance level of $P<0.05$. To account for a dropout rate of $10 \%, 11-12$ subjects per test group were demanded $(n=33)$.

ANTHROPOMETRY AND BODY COMPOSITION ANALYSES

Individuals were measured and weighed, and the body mass index (BMI) in $\mathrm{kg} / \mathrm{m}^{2}$ was calculated and classified based in age and gender according to a standard procedure described by the World Health Organization (Must et al. 1991). The sum of skinfold thicknesses was calculated, and total body fat (percentage) was estimated based on the equations of Slaughter and classified according to Lohman (Heyward and Stolarkzick 2000).

\section{Blood Pressure AsSESSMENT}

Systolic and diastolic blood pressures were measured by age-specific pressure armband equipments on the right arm with the volunteer in a resting state as described by the Brazilian Guidelines of Hypertension (Sociedade Brasileira de Cardiologia 2005). The values were classified considering age and gender, in accordance to the same guidelines.

SERUM MARKERS AND DNA DAMAGE EVALUATION

On a single morning, venous blood samples were drawn from all individuals by vein puncture after a 12-h overnight fast. Serum was obtained 
by centrifugation and was immediately used to measure total cholesterol, HDL, LDL, triglycerides, and glucose concentrations (all in milligrams per deciliter) with a specific commercially available colorimetric assay (BioSystems S.A., Barcelona, Spain) using an automated system (A25 BioSystems S.A., Barcelona, Spain). Whole blood (heparin added) was used for the comet and cytokinesisblocked micronucleus (CBMN) assays.

We used a standard protocol for the comet assay based on silver staining and visual scoring, as described elsewhere (for details see (Friedrisch et al. 2007)). One hundred cells were evaluated per individual (50 each on replicate slides). Cells were visually examined to determine DNA damage scores ranging from class 0 (no migration) to class 4 (maximal migration) based on tail intensity (size and shape). Two DNA damage parameters were calculated accordingly: the damage index (DI), which summed the scores of all 100 cells and ranged from 0 (cells with no migration) to 400 (cells with maximal migration), and the damage frequency (DF), which is the percentage of damaged cells (Da Silva et al. 2000). For the CBMN assay, an aliquot of blood $(0.5 \mathrm{~mL})$ was added to $5 \mathrm{~mL}$ of RPMI 1640 medium supplemented with $20 \%$ fetal calf serum and $0.2 \%$ phytohemagglutinin. The flasks were cultured at $37^{\circ} \mathrm{C}$ for $44 \mathrm{~h}$, after which $4.5 \mathrm{mg} / \mathrm{mL}$ cytochalasin B (Sigma) was added according to the method described by Fenech (1993). The cell suspension was fixed in 3:1 methanol:acetic acid with no hypotonic treatment and dropped onto clean slides. The slides were then stained with Giemsa (10\% during $10 \mathrm{~min}$ ). 2,000 binucleate cells from each individual were scored for micronuclei, nucleoplasmic bridges and nuclear buds (amplified DNA).

\section{DIETARY INTAKE AND OTHER CVD RISK FACTORS}

The intake of selected diet constituents was assessed by $24-\mathrm{h}$ food recalls accessed on three non-consecutive days, as described by Prá et al.
(2011). Information on preexisting CVD in relatives was accessed during anamnesis, and the physical activity level was assessed by the short version of the International Physical Activity Questionnaire (Matsudo et al. 2001).

\section{STATISTICAL ANALYSIS}

Differences between groups were evaluated by the one-way analysis of variance followed by Dunnet's post-hoc or student's t-test (continuous variables) or by chi-square (categorical variables). Linear regressions (Pearson) between DNA damage and the various parameters were also calculated. Data analyses were accomplished using Statistical Package for Social Science (SPSS) version 10.0, and graphs were plotted using Prism version 4.0. The data are expressed as mean ( \pm standard deviation). The level of significance was set at $p<0.05$.

\section{RESULTS}

Table I shows the values of the evaluated variables according to CVD risk level. No differences regarding age $(p=0.19)$ or sex $(p=0.17)$ were observed between groups. Body fat and BMI showed a stepwise increase in conjunction with the CVD risk level. The number of individuals with hypertension differs between groups (only for those individuals with high CVD risk compared with those with low CVD risk), and there was a significant correlation between hypertensive subjects and an increased CVD risk level ( $\mathrm{r}=0.370, \mathrm{p}=0.031$; Table I).

The levels of fasting glucose, total cholesterol and LDL, but not HDL, were significantly higher in individuals with moderate and high CVD risk in relation to those individuals with low CVD risk. Triglycerides were significantly higher only for those individuals with high CVD risk compared with those with low or moderate CVD risk.

Regarding the level of primary DNA damage, DI and DF indicated that there were a two-fold increase from low to moderate, and another two- 
TABLE I

Different parameters in a sample of children and adolescents with different levels of cardiovascular risk.

\begin{tabular}{|c|c|c|c|}
\hline \multirow{2}{*}{ Parameters } & \multicolumn{3}{|c|}{ Cardiovascular risk\# } \\
\hline & Low $(n=11)$ & Moderate $(n=11)$ & High $(n=12)$ \\
\hline \multicolumn{4}{|l|}{ Anthropometry } \\
\hline Age (years) & $11.36 \pm 3.23$ & $10.55 \pm 3.14$ & $12.75 \pm 2.22$ \\
\hline Females (n) & 5 & 9 & 6 \\
\hline BMI $\left(\mathrm{kg} / \mathrm{m}^{2}\right)$ & $19.24 \pm 3.49$ & $22.83 \pm 7.41$ & $28.6 \pm 5.08^{\mathrm{ab}}$ \\
\hline Body fat $(\%)$ & $17.34 \pm 6.37$ & $26.54 \pm 10.61^{\mathrm{a}}$ & $38.46 \pm 8.09^{\mathrm{ab}}$ \\
\hline Hypertension (n) & 1 & 3 & $6 *$ \\
\hline \multicolumn{4}{|l|}{ Serum markers } \\
\hline Fasting glucose (mg/dL) & $77.91 \pm 5.91$ & $85.91 \pm 9.68^{\mathrm{a}}$ & $85.5 \pm 5.60^{\mathrm{a}}$ \\
\hline Total cholesterol (mg/dL) & $151.45 \pm 10.32$ & $170.18 \pm 18.59^{\mathrm{a}}$ & $189.83 \pm 21.83^{a b}$ \\
\hline HDL (mg/dL) & $46.18 \pm 4.56$ & $48.55 \pm 9.75$ & $51.92 \pm 9.13$ \\
\hline $\mathrm{LDL}(\mathrm{mg} / \mathrm{dL})$ & $92.36 \pm 16.88$ & $110.36 \pm 11.94^{\mathrm{a}}$ & $119.58 \pm 11.07^{\mathrm{a}}$ \\
\hline Triglicerydes (mg/dL) & $66.73 \pm 13.74$ & $66.64 \pm 12.53$ & $110.00 \pm 37.96^{\mathrm{ab}}$ \\
\hline \multicolumn{4}{|l|}{ DNA damage } \\
\hline Damage index (mean \pm s.d.) & $7.64 \pm 3.96$ & $15.09 \pm 5.66$ & $31.83 \pm 8.97^{\mathrm{ab}}$ \\
\hline Damage frequency $(\%)$ & $5.55 \pm 2.84$ & $11.27 \pm 4.52$ & $23.08 \pm 6.79^{a b}$ \\
\hline Micronuclei (\%o) & $6.79 \pm 4.48$ & $7.65 \pm 3.08$ & $5.52 \pm 2.66$ \\
\hline Nucleoplasmic bridges (\%o) & $2.58 \pm 2.83$ & $2.57 \pm 1.20$ & $1.88 \pm 2.32$ \\
\hline Nuclear buds (\%o) & $7.29 \pm 5.54$ & $7.52 \pm 1.76$ & $10.32 \pm 6.27$ \\
\hline Family history of CVD (n) & 3 & $9 *$ & $9 *$ \\
\hline Low physical activity (n) & 4 & 6 & 8 \\
\hline \multicolumn{4}{|l|}{ Diet } \\
\hline Lipids ( $\%$ total calories) & $28.62 \pm 4.94$ & $32.68 \pm 6.99$ & $31.62 \pm 6.31$ \\
\hline Cholesterol (mg/day) & $249.86 \pm 87.24$ & $234.45 \pm 96.51$ & $235.67 \pm 152.08$ \\
\hline Fibers (g/day) & $13.87 \pm 4.80$ & $11.91 \pm 5.28$ & $12.84 \pm 5.09$ \\
\hline Vitamin A ( $\mu \mathrm{g} /$ day) & $586.22 \pm 424.68$ & $558.88 \pm 355.53$ & $420.35 \pm 330.39$ \\
\hline Vitamin C (mg/day) & $60.84 \pm 41.11$ & $67.38 \pm 47.25$ & $40.93 \pm 28.95$ \\
\hline Vitamin E (mg/day) & $11.19 \pm 8.23$ & $13.91 \pm 4.94$ & $9.93 \pm 5.69$ \\
\hline Folate ( $\mu \mathrm{g} /$ day $)$ & $151.98 \pm 94.78$ & $151.69 \pm 81.83$ & $149.58 \pm 76.71$ \\
\hline
\end{tabular}

\#Low cardiovascular risk was defined as those subjects with no cardiovascular risk factors; moderate cardiovascular risk was defined as those subjects with one or two cardiovascular risk factor; and high cardiovascular risk was defined as those subjects with three or more cardiovascular risk factors. $* P<0.05$ with respect to low cardiovascular disease risk, as evaluated with the chi-square test; ${ }^{\mathrm{a}} P<0.01$ with respect to low cardiovascular risk and ${ }^{\mathrm{b}} P<0.01$ with respect to moderate cardiovascular risk, according to ANOVA followed by Dunnet's multiple comparison test.

fold increase from moderate to high CVD risk level (Table I). Most damaged cells from moderate and high CVD risk subjects were classified as of low DNA damage scores (classes 1 and 2) (Fig. 1).
In agreement with the low DNA damage scores, no noticeable effect of CVD risk on the level of micronuclei, nucleoplasmic bridges or nuclear buds was observed (Table I). 




Figure 1: DNA damage classes according to the comet assay in a sample of children and adolescents with variable cardiovascular risks.

The number of individuals with family history of CVD differed between groups ( $\mathrm{p}=0.016$ ) and correlated positively with an increase in CVD risk level $(\mathrm{r}=0.393, \mathrm{p}=0.022)$. There was a non-significant trend for an increase in physical inactivity towards the high CVD risk group. On the contrary, there were no significant differences regarding the intake of the evaluated nutrients between the groups.
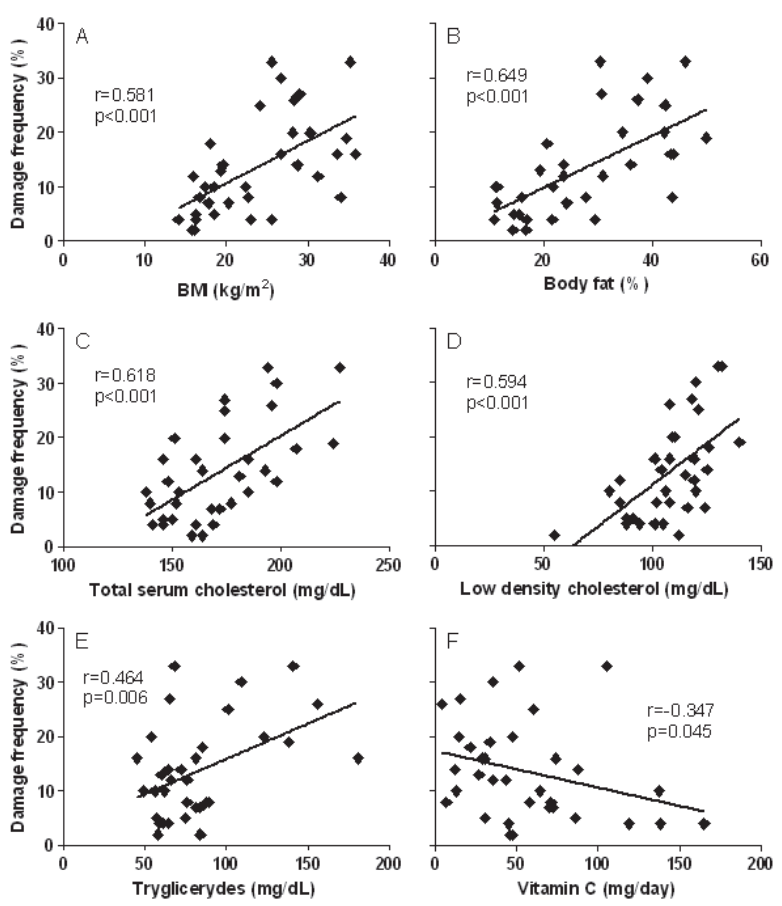

Figure 2: Association between DNA damage level as evaluated by damage frequency and body mass index (A), body fat (B), serum cholesterol (C), low density cholesterol (D), triglycerides (E) and dietary vitamin $\mathrm{C}(\mathrm{F})$ in a sample of children and adolescents with variable cardiovascular risks.
The level of DNA damage as evaluated by the comet assay was correlated positively with various CVD risk parameters (BMI, body fat, total cholesterol, LDL and triglycerides, Fig. 2a-e). Regarding diet, the intake of vitamin $\mathrm{C}$ was inversely correlated with the DNA damage level as evaluated by the comet assay $(r=-0.347, p=0.045$; Fig. $2 \mathrm{f}$ ); and the folic acid intake was inversely related to the frequency of micronuclei $(\mathrm{r}=-0.525, \mathrm{p}=0.012)$, nucleoplasmic bridges $(\mathrm{r}=-0.539, \mathrm{p}=0.010)$ and nuclear buds ( $\mathrm{r}=-0.592, \mathrm{p}=0.004)$ (Fig.3).
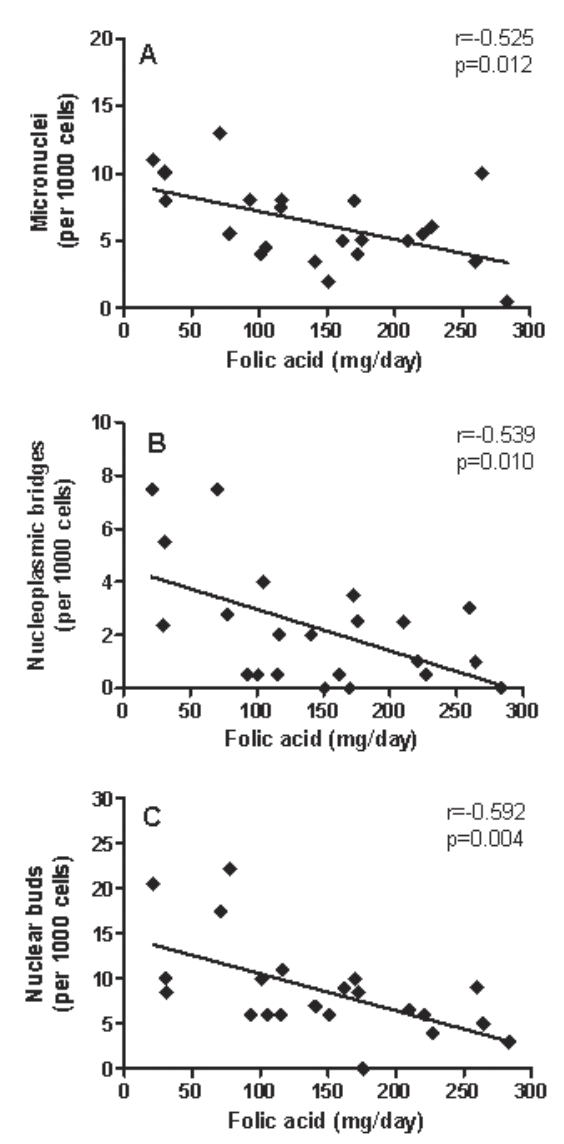

Figure 3: Association between the folic acid intake and frequency of micronuclei (A), nucleoplasmic bridges (B) and nuclear buds (C) in a sample of children and adolescents with variable cardiovascular risks.

Hypertensive individuals had about two-fold more DNA damage than the normotensive subjects (DI: $25.50 \pm 13.54$ versus $15.71 \pm 10.62 ; \mathrm{p}=0.031$; and DF: $20.00 \pm 9.21$ versus $10.92 \pm 7.52 ; \mathrm{p}=0.005)$. 
There was no significant difference in DNA damage level depending on familial history of CVD or physical activity level.

\section{DISCUSSION}

There is evidence that the primary prevention of CVD must start early in life (Washington 1999). Moreover, Federici et al. (2008) have hypothesized that circulating levels of DNA damage may have a prognostic value in patients with CVD. We evaluated primary DNA damage in the comet assay, which identifies DNA single or double strand breaks that could be repaired by the cells. DNA strand breaks can occur as a consequence of the action of DNA excision repair, which cleaves DNA previously to its resynthesis, and is detected as a momentaneous DNA strand breaks, as well as can originate from alkali-labile sites that are converted to DNA strand breaks due to the alkaline condition of the comet assay (Da Silva et al. 2000, Tice et al. 2000). We evaluated permanent chromosomal DNA damage in the CBMN assay, which quantifies micronuclei (which are a consequence of chromosome breaks or loss during cell division), nucleoplasmic bridges (chromosome rearrangements) and nuclear buds (DNA amplification) (Fenech et al. 2003, 2011).

The present results indicated an increase in primary, but not permanent, DNA damage, suggesting that the DNA lesions were of low extension and could be effectively repaired in the evaluated subjects. Indeed, as shown in Figure 1, most cells of all subjects showed no or low levels of DNA damage, with more than $70 \%$ of the cells showing no DNA damage, irrespective of the CVD risk group. Although the high CVD risk group showed a noticeable increase in primary DNA damage, many authors have proposed that such DNA lesions (which fall into classes 1 and 2) include mainly DNA single strand breaks, which are readily repaired and are not associated with DNA double strand breaks (Da Silva et al. 2000, Tice et al. 2000).
The positive association between CVDassociated outcomes and oxidative stress markers, including lymphocyte DNA damage, has been shown in adults with CVD (Kim et al. 2008). There is also a relationship between oxidative primary DNA damage and endothelial function in patients with CVD (Yurdakul et al. 2008). Moreover, a prospective cohort study with adults with CVD showed that the levels of peripheral chromosomal DNA damage may act as a sensitive biomarker of prognosis for CVD outcomes within a 5-year follow-up period (Federici et al. 2008). Notwithstanding, no study to date has evaluated the association of DNA damage markers in children or adolescents with variable levels of CVD risk factors, such as obesity and lipid metabolism abnormalities. Indeed, the present results indicated a positive correlation between primary DNA damage and anthropometrical measures or lipid metabolism markers. Visceral fat accumulation and lipid metabolism disturbances, even in non-obese individuals, are major factors that contribute to increase CVD risk and are associated with primary DNA damage levels (Jang et al. 2003). Children with a metabolic syndrome have elevated levels of subclinical inflammation, oxidative stress increase and lipid metabolism abnormalities in comparison with normal-weight controls (Kelly et al. 2006).

Regarding arterial pressure, hypertensive subjects had higher DNA damage levels than the normotensive ones. Although no study has directly evaluated the effect of hypertension on DNA damage, a recent population study has shown that hypertension was the strongest determinant of oxidative stress in subjects with high CVD risk (Fandos et al. 2009).

The intake of antioxidant vitamins not as supplements, but within a healthy diet, reduces CVD risks (Eichholzer et al. 2001, Obrenovich et al. 2011). Despite controversies, there is evidence that antioxidant vitamins may inhibit LDL oxidation to its more atherogenic form, therefore preserving the inhibition of atherosclerotic plaque formation 
(Wattanapitayakul and Bauer 2001). Vitamin C and folate are also associated with lower levels of primary and permanent DNA damage, respectively. An inverse relationship between vitamin C intake and CVD mortality has been shown (Simon 1992), and the effect of vitamin C on DNA damage has been extensively studied (Franke et al. 2005). Folic acid intake has been associated with the risk of many diseases, including CVD (Doshi et al. 2003). Folate status is among a number of host risk factors for which there is strong or sufficient evidence that they affect background levels of genotoxicity biomarkers (Battershill et al. 2008, Fenech et al. 2011), and the background frequency of micronuclei has been historically associated with folate intake (Fenech et al. 2005, 2011).

The findings of the current study suggest that, compared with low CVD risk, high CVD risk children and adolescents have the highest levels of primary DNA damage, but they did not differ in terms of permanent DNA damage. CVD risk factors, such as adiposity, hypertension, total cholesterol, LDL and triglycerides, correlated with primary DNA damage level. Although there were minor differences regarding diet between the groups with different CVD risks, the intake of vitamin $\mathrm{C}$ and folic acid correlated negatively with the extent of primary and permanent DNA damage, respectively. Given the oxidative stress theory of CVD origin and progression, as well as the evidence of increased chromosome DNA damage in adults with CVD, evaluating DNA damage in early stages of life may identify those individuals who are more likely to suffer from cardiovascular morbidity and mortality. Studies are needed to further examine the progression of DNA lesions throughout the lifespan of individuals with CVD risk factors.

\section{RESUMO}

$\mathrm{O}$ risco de desenvolver doença cardiovascular (DCV) está relacionado ao estilo de vida (por exemplo, dieta, atividade física e tabagismo), bem como a fatores genéticos. Este estudo teve como objetivo avaliar a associação entre fatores de risco cardiovascular e os níveis de danos ao DNA em crianças e adolescentes. Antropometria, dieta e fatores de risco para DCV foram avaliados através de procedimentos padrão. Níveis de danos no DNA foram avaliados através do ensaio cometa (eletroforese de célula única; EC) e do teste de micronúcleos em leucócitos. Um total de 34 crianças e adolescentes, selecionados a partir de uma amostra populacional, foram divididos em três grupos, de acordo com seu nível de risco de DCV. Indivíduos com níveis moderado e alto risco para DCV apresentaram de forma significativa maiores níveis de gordura corporal e de marcadores séricos de risco cardiovascular que indivíduos de baixo risco $(P<0,05)$. Indivíduos de alto risco também mostraram um aumento significativo de danos ao DNA, de acordo com o EC, mas não de acordo com o teste de micronúcleos, doqueindivíduos de risco baixoe moderado. A vitamina $\mathrm{C}$ consumida foi inversamente correlacionada com os danos ao DNA avaliados pelo EC, e o número de micronúcleos foi inversamente correlacionado com a ingestão de ácido fólico. Os resultados obtidos indicam um aumento de danos no DNA que pode ser consequente do estresse oxidativo em indivíduos jovens com fatores de risco para DCV, indicando que o nível de danos no DNA pode auxiliar na avaliação do risco de DCV.

Palavras-chave: doenças cardiovasculares, Teste de micronúcleos, Ensaio cometa, dieta, antropometria, criança, adolescente.

\section{REFERENCES}

Argiles JM, CARBo N, Costelli P AND LOPEZ-SORIANO FJ. 1998. Prevention of cancer and cardiovascular diseases: a common strategy? Med Res Rev 18: 139-148.

BATTERShILl JM, BURNETT K AND BULL S. 2008. Factors affecting the incidence of genotoxicity biomarkers in peripheral blood lymphocytes: impact on design of biomonitoring studies. Mutagenesis 23: 423-437.

Berenson GS, SRINIVASAN SR, BaO WH, NEWMan WP, Tracy RE AND WATTIGNEY WA. 1998. Association between multiple cardiovascular risk factors and atherosclerosis in children and young adults. N Engl J Med 338: 1650-1656.

DA SILVA J, FreITAS T, MARINHO J, SPEIT G AND ERDTMANN B. 2000. An alkali single-cell gel eletroforesis (comet) assay for environmental biomonitoring with native rodents. Genet Mol Biol 23: 241-245. 
Doshi S, McDowell I, MOAT S, LEWIS M AND GOODFELlow J. 2003. Folate improves endothelial function in patients with coronary heart disease. Clin Chem Lab Med 41: 1505-1512.

EICHHOLZER M, LUTHY J, GUTZWILLER F AND STAHELIN H. 2001. The role of folate, antioxidant vitamins and other constituents in fruit and vegetables in the prevention of cardiovascular disease: the epidemiological evidence. Int J Vitam Nutr Res 71: 5-17.

FANDOS M ET AL. 2009. Impact of cardiovascular risk factors on oxidative stress and DNA damage in a high risk Mediterranean population. Free Rad Res 43: 1179-1186.

FEDERICI C, BotTo N, MANFREdi S, Rizza A, DEL FiANDRA M AND ANDREASSI M. 2008. Relation of Increased Chromosomal Damage to Future Adverse Cardiac Events in Patients With Known Coronary Artery Disease. Am J Cardiol 102: 1296-1300.

FENECH M. 1993. The cytokinesis-block micronucleus technique: a detailed description of the method and its application to genotoxicity studies in human populations. Mutat Res 285: 35-44.

FENECH M, BAghurst P, LUderer W, TURner J, RECORd S, CEPPI M AND BONASSI S. 2005. Low intake of calcium, folate, nicotinic acid, vitamin E, retinol, beta-carotene and high intake of pantothenic acid, biotin and riboflavin are significantly associated with increased genome instability-results from a dietary intake and micronucleus index survey in South Australia. Carcinogenesis 26: 991-999.

Fenech M, Chang W, Kirsch-Volders M, Holland N, BONASSI S AND ZEIGER E. 2003. HUMN project: detailed description of the scoring criteria for the cytokinesis-block micronucleus assay using isolated human lymphocyte cultures. Mutat Res 534: 65-75.

FENECH M, Kirsch-Volders M, Natarajan AT, Surralles J, CROTT JW, PARry J, NorpPa H, EASTMOND DA, TUCKER JD AND THOMAS P. 2011. Molecular mechanisms of micronucleus, nucleoplasmic bridge and nuclear bud formation in mammalian and human cells. Mutagenesis 26: $125-132$.

Franke S, PrÁ D, da Silva J, ERdTMann B AND Henriques J. 2005. Possible repair action of Vitamin C on DNA damage induced by methyl methanesulfonate, cyclophosphamide, FeSO4 and $\mathrm{CuSO} 4$ in mouse blood cells in vivo. Mutat Res 583: 75-84.

Friedrisch J, Prá D, Maluf S, Bittar C, Mergener M, Pollo T, Kayser M, Silva M, Henriques J AND Silla L. 2007. DNA damage in blood leukocytes of individuals with sickle cell disease treated with hydroxyurea. Mutat Res 649: 213-220.

HEYWARD V AND STOLARKZICK L. 2000. Avaliação da composição corporal aplicada, São Paulo, Manole, 243 p.

JANG Y, KiM O, RYu H, KIM J, SONG S, ORdOVAS J AND LEE J. 2003. Visceral fat accumulation determines postprandial lipemic response, lipid peroxidation, DNA damage, and endothelial dysfunction in nonobese Korean men. J Lipid Res 44: 2356-2364.

Kelly A, Steinberger J, Kaiser D, Olson T, Bank A And DENGEL D. 2006. Oxidative stress and adverse adipokine profile characterize the metabolic syndrome in children. J Cardiometab Syndr 1: 248-252.
Kim J, Hyun Y, Jang Y, LeE B, Chae J, Kim S, Yeo H, JeOng T, JEON D AND LEE J. 2008. Lipoprotein-associated phospholipase $\mathrm{A}(2)$ activity is associated with coronary artery disease and markers of oxidative stress: a casecontrol study. Am J Clin Nutr 88: 630-637.

LLOYD-JONES DM, LARSON M, BEISER A AND LEVY D. 1999. Lifetime risk of developing coronary heart disease. Lancet 353: 89-92.

Matsudo S, Timóteo A, Matsudo V, Andrade D, Andrade E AND OLIVEIRA L. 2001. Questionário Internacional de Atividade Física (IPAC): estudo de validade e reprodutibilidade no Brasil. Rev Bras Ativ Fis Saúde 6: 5-18.

Must A, Dallal G AND Dietz W. 1991. Reference data for obesity: $85^{\text {th }}$ and $95^{\text {th }}$ percentiles of body mass index (wt/ht 2 ) and triceps skinfold thickness. Am J Clin Nutr 53: 839-846.

Must A, Jacques P, Dallal G, Bajema C and Dietz W. 1992. Long-term morbidity and mortality of overweight adolescents. A follow-up of the Harvard Growth Study of 1922 to 1935. N Engl J Med 327: 1350-1355.

OBRENOVICH M, Li Y, PARVATHANENI K, YendLURI B, PALACIOS H, LESZEK J AND ALIEV G. 2011. Antioxidants in health, disease and aging. CNS and Neurological Disorders Drug Targets 10: 192-207.

POULSEN H. 2005. Oxidative DNA modifications. Exp Toxicol Pathol 57: 161-169.

PrÁ D, Bortoluzzi A, MÜller L, Hermes L, Horta J, Maluf S, Henriques J, Fenech M and Franke S. 2011. Iron intake, red cell indicators of iron status and DNA damage in young subjects. Nutrition 27: 293-297.

SimON J. 1992. Vitamin-C and Cardiovascular-Diseasea Review. J Am Coll Nutr 11: 107-125.

SOCIEDADE BRASILEIRA DE CARDIOLOGIA. 2005. I Diretriz de Prevenção da Aterosclerose na Infância e na Adolescência. Arq Bras Cardiol 85: 3-36.

Tice R, Agurell E, ANderson D, Burlinson B, Hartmann A, Kobayashi H, Miyamae Y, Rojas E, Ryu J And SASAKI Y. 2000. Single cell gel/comet assay: guidelines for in vitro and in vivo genetic toxicology testing. Environ Mol Mutagen 35: 206-221.

WASHINGTON R. 1999. Interventions to reduce cardiovascular risk factors in children and adolescents. Am Fam Physician 59: 2211-2218.

WATTANAPITAYAKUL S AND BAUER J. 2001. Oxidative pathways in cardiovascular disease: roles, mechanisms, and therapeutic implications. Pharmacol Therapeut 89: 187-206.

WU L. 1999. Review of risk factors for cardiovascular diseases. Ann Clin Lab Sci 29: 127-133.

Yurdakul S, OzBen B, Bilge A, Turkoglu U, Arkaya S AND NISANCI Y. 2008. Oxidative DNA damage is significantly correlated with flow-mediated dilation in patients with coronary artery disease. J Invest Med 56: 925-930. 